\title{
In halt
}

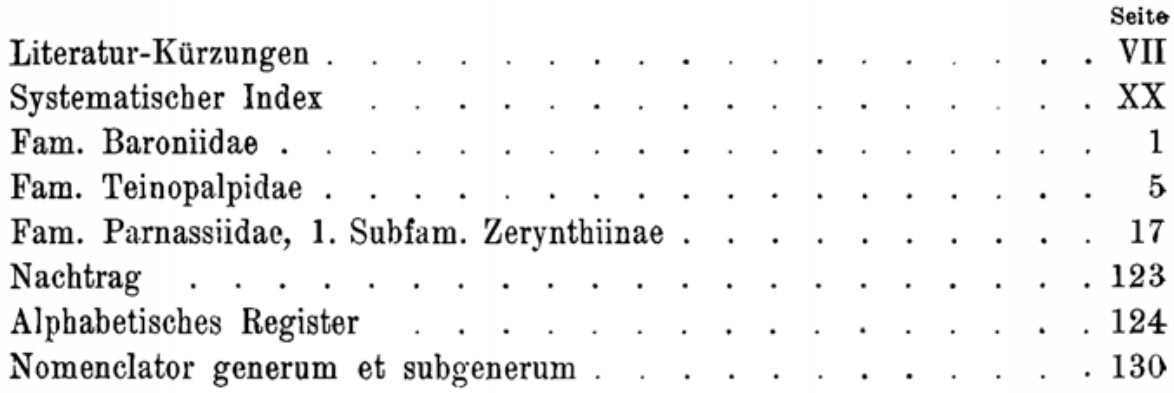

Die Literatur wurde bis Ende des Jahres 1933 berücksichtigt.

Die Originalzeichnungen hat Professor Dr. M. Hering zur Verfügung gestellt, wofür ihm der Autor seinen verbindlichsten Dank ausspricht. 
